\title{
Uorden
}

Nordisk Ministerråd

\section{Norden - førende inden for grøn vækst}

Status til de nordiske statsministres sommermøde 2015

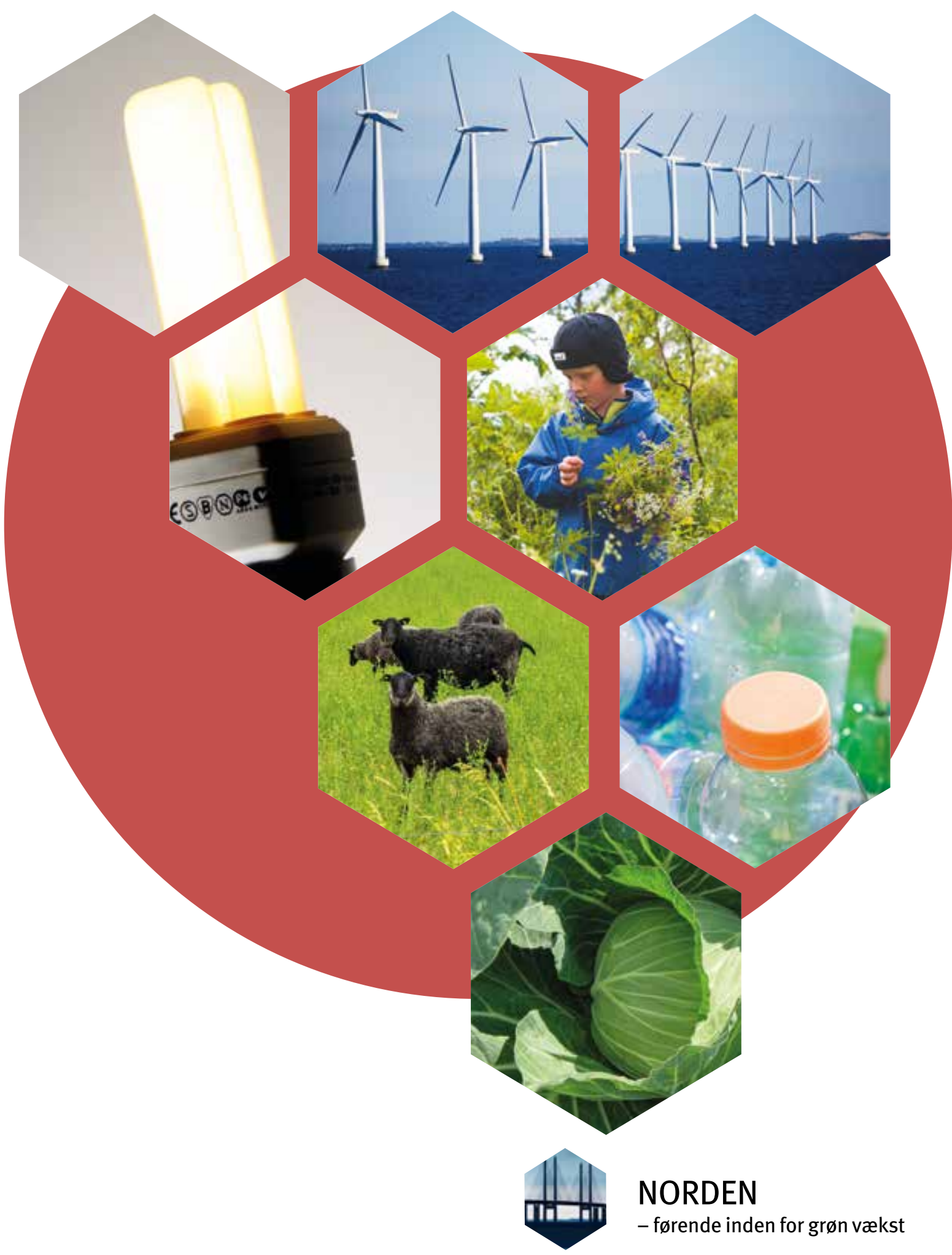


ISBN 978-92-893-4190-5 (PRINT)

ISBN 978-92-893-4191-2 (PDF)

http://dx.doi.org/10.6027/ANP2015-730

ANP 2015:730

(C) Nordisk Ministerråd 2015

Layout: Gitte Wejnold

Foto: Norden.org; Colourbox; ImageSelect

Typsnitt: Meta LF

Papir: Munken Polar

Oplag: 200

Tryk: Rosendahls-Schultz Grafisk

Printed in Denmark

www.norden.org/nordpub

\section{Det nordiske samarbejde}

Det nordiske samarbejde er en af verdens mest omfattende regionale samarbejdsformer. Samarbejdet omfatter Danmark, Finland, Island, Norge og Sverige samt Færøerne, Grønland og Åland.

Det nordiske samarbejde er både politisk, økonomisk og kulturelt forankret og er en vigtig medspiller i det europæiske og internationale samarbejde. Det nordiske fællesskab arbejder for et stærkt Norden i et stærkt Europa.

Det nordiske samarbejde ønsker at styrke nordiske og regionale interesser og værdier i en global omverden. Fælles værdier landene imellem er med til at styrke Nordens position som en af verdens mest innovative og konkurrencedygtige regioner.

Nordisk Ministerråd

Ved Stranden 18

1061 København K

Telefon (+45) 33960200 


\title{
Norden - førende inden for grøn vækst
}

\author{
Status til de nordiske statsministres sommermøde 2015
}

\section{Forord}

Grøn vækst har været en af Nordisk Ministerråds prioriterede satsninger, siden programmet blev skudt i gang af de nordiske statsministre i november 2011 med det formål at gøre Norden førende inden for grøn vækst.

Statsministrenes vision for programmet har været at identificere områder, hvor de nordiske lande kan bygge videre på eksisterende styrkepositioner, forbedre samordningen mellem de nordiske lande og indtage en førerposition med hensyn til udviklingen inden for EU. Som generalsekretær for Nordisk Ministerråd glæder det mig at kunne konstatere, at Norden har gjort store fremskridt på alle disse områder.

De forskellige indsatser spænder over et bredt område: uddannelse og forskning, elmarkedet, byggesektoren, økodesign og energieffektivisering, samarbejde om grønne offentlige indkøb, affaldshåndtering, testcentre, udviklingssamarbejdet og grønne investeringer. Alle disse indsatser har til formål at imødegå de store miljø- og klimaudfordringer samt at bidrage til, at de nordiske lande kan forbedre deres markedspositioner.

Sammenlagt har Nordisk Ministerråd bevilget over 66 millioner danske kroner til programmets otte indsatsområder i 2012-2015. De fleste initiativer forventes at være afsluttede inden udgangen af 2015 , mens en del aktiviteter vil fortsætte helt ind i 2016. De mere langsigtede resultater og politiske effekter kan vi dog først forvente at se og høste frugten af i de kommende år.

Allerede nu kan vi dog se, at programmets resultater peger på et stort potentiale for at forbedre ressourceeffektiviteten i Norden, reducere udledningen af drivhusgasser og skabe nye arbejdspladser i regionen. Alene en omstilling af tekstilindsamling og -genbrug kan føre til 4.000 nye arbejdspladser. Dét er grøn vækst i praksis!

Programmet Grøn vækst har skabt et stærkt fundament for Nordisk Ministerråds fortsatte arbejde med innovative grønne løsninger. Nordisk Ministerråd vil i 2015 fortsætte med at formidle resultaterne fra programmet i flere internationale fora med det formål at udbrede vores positive nordiske erfaringer til en bredere målgruppe.

Jeg er overbevist om, at vi via programmet har bidraget til at styrke de nordiske kompetencer, forbedret samordningen mellem de nordiske lande og positioneret os internationalt som en region, hvor grøn vækst, innovation og bæredygtig udvikling er en realitet - ikke kun en fremtidsvision.

\section{Dagfinn Høybråten}

Generalsekretær

Nordisk Ministerråd

\section{Statsministrenes otte indsatser:}

Nordiske testcentre for grønne løsninger fokus på bioøkonomi og bioraffinaderier

Uddannelse og forskning, som fremmer grøn vækst

Forbrugerfleksibilitet på det nordiske elmarked

4 Grønne tekniske normer og standarder

5 Grønne offentlige indkøb i Norden

6 Udvikling af teknologi og metoder til affaldshåndtering

7 Integrering af miljø og klima i udviklingssamarbejdet

Finansiering af grønne investeringer og virksomheder 


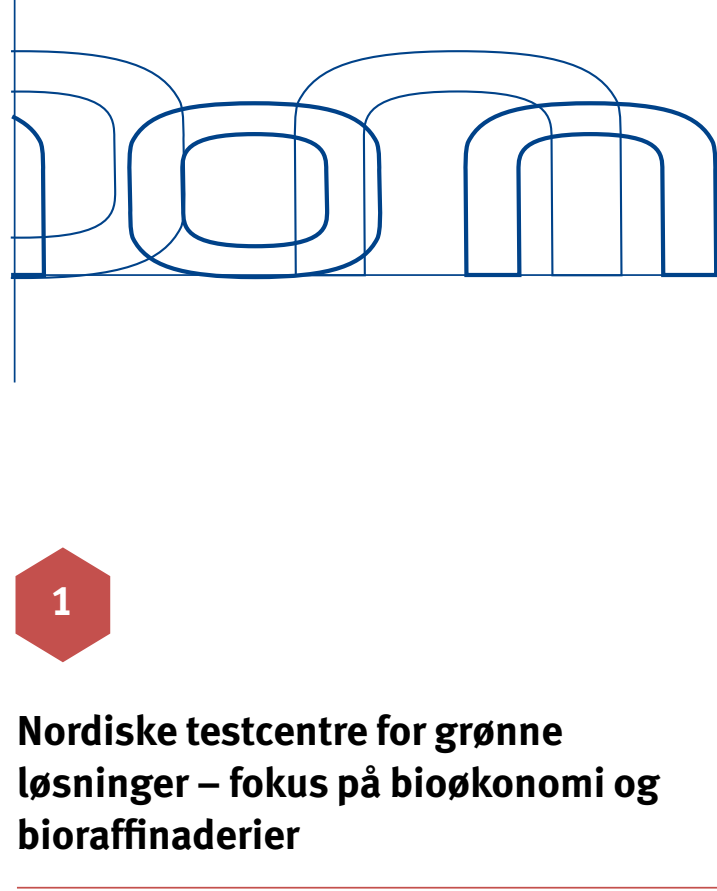

\section{Opdrag:}

- Undersøge mulighederne for et nordisk samarbejde om eksisterende nationale ordninger, hvor energiteknologi kan testes og udvikles $\mathrm{i}$ stor skala

- Undersøge mulighederne for og nytten af at etablere nye fælles nordiske test- og demonstrationsanlæg

\section{Ansvar:}

Energiministrene i samarbejde med erhvervs-, forsknings, transport- og landbrugsministrene

Projektet har resulteret i policyanbefalinger om etableringen af et nordisk samarbejde omkring bioraffinaderier. Anbefalingerne fremhæver blandt andet bioøkonomiens evne til at bidrage til udvikling i landdistrikter og kystområder og skabe vækst i små og mellemstore virksomheder.

Anbefalingerne bliver i løbet af 2015 behandlet af ministerrådene for Fiskeri, Havbrug, Jordbrug, Levnedsmidler og Skovbrug (MR-FJLS) og Energi-, Erhvervs- og Regionalpolitik (MR-NER) og forventes at lede til fortsat samarbejde og opfølgning på området.

Indsatsen omkring testcentrene blev indledt i 2012 med kortlægningen Mapping Green Energy Test Facilities and Demonstration Sites in the Nordic Countries, som beskriver 45 eksisterende test- og demonstrationsanlæg i Norden. Kortlægningen viste, at der er potentiale for øget nordisk samarbejde på området, og at der ville være fordele i at dele de høje investerings- og driftsomkostninger.

Med udgangspunkt i kortlægningen valgte fiskeri-, havbrugs-, levnedsmiddels-, landbrugs- og skovbrugsministrene, i samarbejde med erhvervsministrene, at fortsætte med at undersøge mulighederne for et nordisk samarbejde omkring bioraffinaderier for at

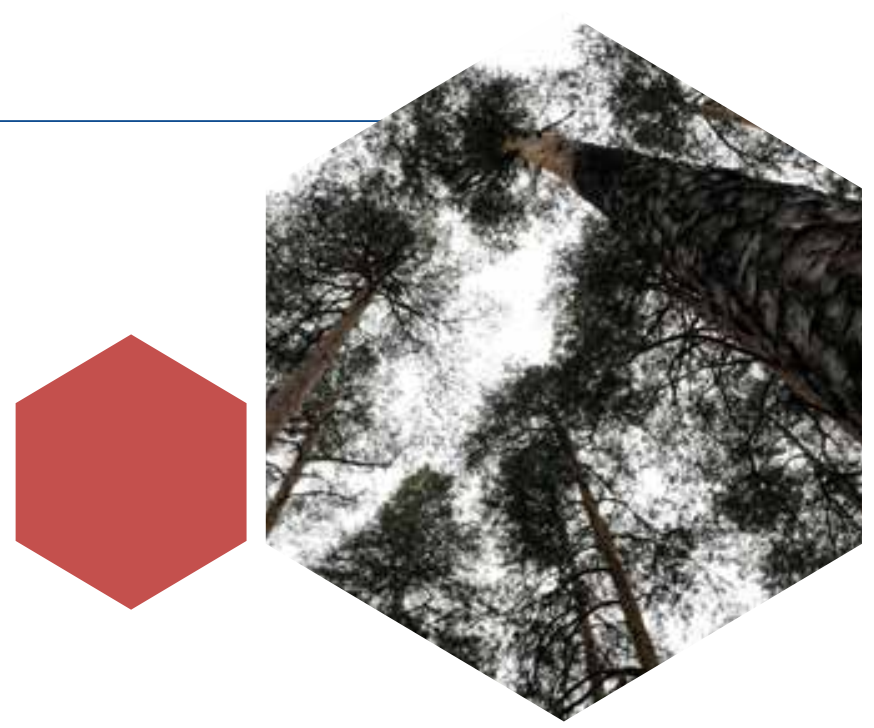

optimere udnyttelsen af biologiske ressourcer, som enten er underudnyttede eller slet ikke udnyttes i dag.

Bioraffineringsanlæg til opgradering af side- og affaldsstrømme fra primærindustrierne er allerede etableret flere steder, men på nuværende tidspunkt er udviklingen langsom og produkterne oftest afgrænset til lavværdi-områder som energi og gødning. Allerede kendte teknologier rummer til gengæld mulighed for at opgradere organiske ressourcer til hele værdispektret af produkter, fra sundhed over foder- og fødevareingredienser, kemikalier og funktionelle materialer til energi og jordforbedring.

En af anbefalingerne er at gøre bioøkonomi til en fælles nordisk højprioritet for at muliggøre hurtigere implementering. Det indebærer, at landene skal gå sammen om forskning og udvikling af teknologier og anlæg til opgradering af organisk affald og restprodukter fra primærindustrierne til både højværdiprodukter og energi.

Landene opfordres også til at udvikle incitamentsstrukturer, som skaber et marked for nye bioraffineringsprodukter, og påvirke EU's regler, som utilsigtet modvirker udbygning af bioøkonomiens ressourceeffektivitet og potentialet i den cirkulære økonomi.

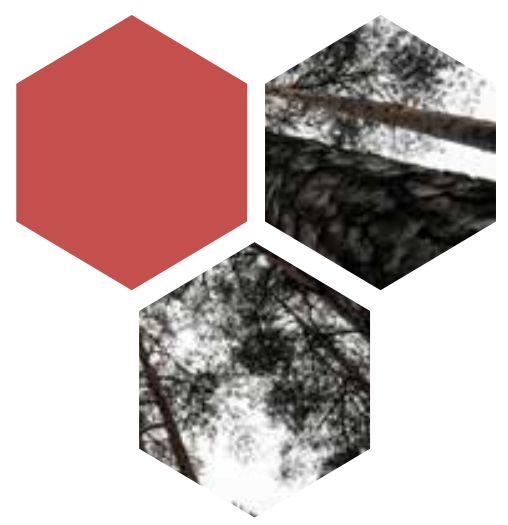



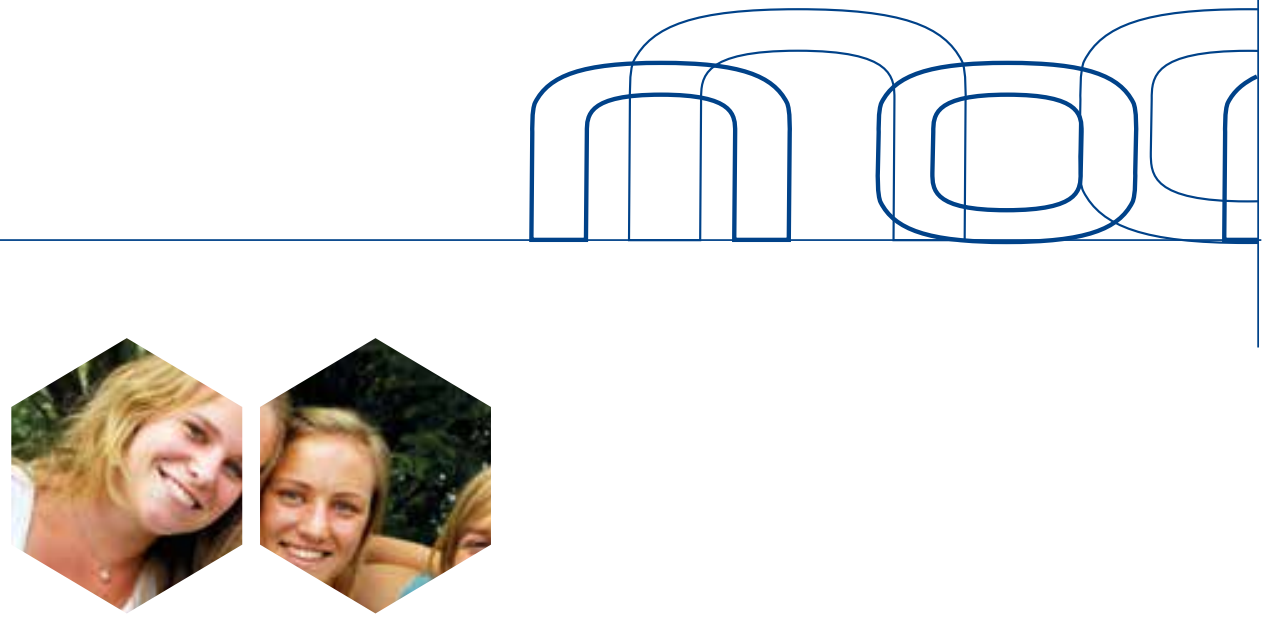

\section{Uddannelse og forskning, som fremmer grøn vækst}

\section{Opdrag: \\ - At udvikle nordisk samarbejde omkring uddannelse og forskning, som fremmer grøn vækst}

\section{Ansvar:}

Uddannelses- og forskningsministrene i samarbejde med energi og erhvervsministrene

Seks forskellige projekter er etableret på indsatsområdet uddannelse og forskning. Projekterne dækker hele uddannelsesspektret fra børn og unge til voksne med et fælles mål om at styrke bæredygtig udvikling og grøn vækst. Projekterne er nået bredt ud til et stort antal uddannelsesinstitutioner i Norden. Den største enkelte satsning er et fælles nordisk forskningsprojekt, som forventes at få et samlet budget på 80 millioner norske kroner.

\section{Green Growth - Understanding Societal Challenges} De fem nordiske lande går nu sammen om at udvikle et større tværfagligt forsknings- og innovationsprogram om grøn vækst, som har fået arbejdstitlen Green Growth - Understanding Societal Challenges. Programmet bringer førende forskere i Norden inden for klima, miljø og energi sammen med erhvervsliv og innovationsmiljøer med henblik på at omsætte teorier og ambitioner om grøn vækst til praksis i nordisk erhvervs- og arbejdsliv.

Programmet vil fokusere på områder inden for forskning og innovation for grøn vækst, hvor Norden har fælles interesser og kan bidrage med løsninger internationalt. Der skal skabes synergier i forhold til andre relevante initiativer i Norden og internationalt, såsom det nordiske program for Arktisforskning, det planlagte nordiske samarbejde om bioøkonomi og Topforskningsinitiativet (TFI), som har skabt gode resultater inden for klima- og miljøforskning.

En vigtig prioritering vil være at belyse de samfundsmæssige forhold knyttet til grøn vækst og politikimplikationer af denne viden. Programmet vil bidrage til bred anvendelse af resultaterne inden for uddannelse, forskning, erhvervsliv og forvaltning. Det samlede budget bliver omkring 80 millioner NOK, som ud over grøn vækst-midlerne finansieres af NordForsk, Nordic Innovation og Nordisk Energiforskning samt forsknings- og innovationsinstitutioner i alle de nordiske lande.

\section{Nordisk klimaduel og læringsportal}

Nordisk Klimadag 2014 blev startskuddet for Den Store Nordiske Klimaduel - en konkurrence om energibesparelse mellem 6.-10.-klasseselever i Norden, som kombinerer undervisningsmateriale, temaer og konkurrencer om energi, klima og miljø.

Formålet er at tilbyde nordisk undervisningsmateriale, som motiverer til samarbejde mellem eleverne og gør dem mere bevidste om deres ansvar og handlekompetencer i forhold til afhjælpning af klima- og miljøudfordringer. Indholdet er tilgængeligt på fem sprog og er fuldt integreret på læringsportalen

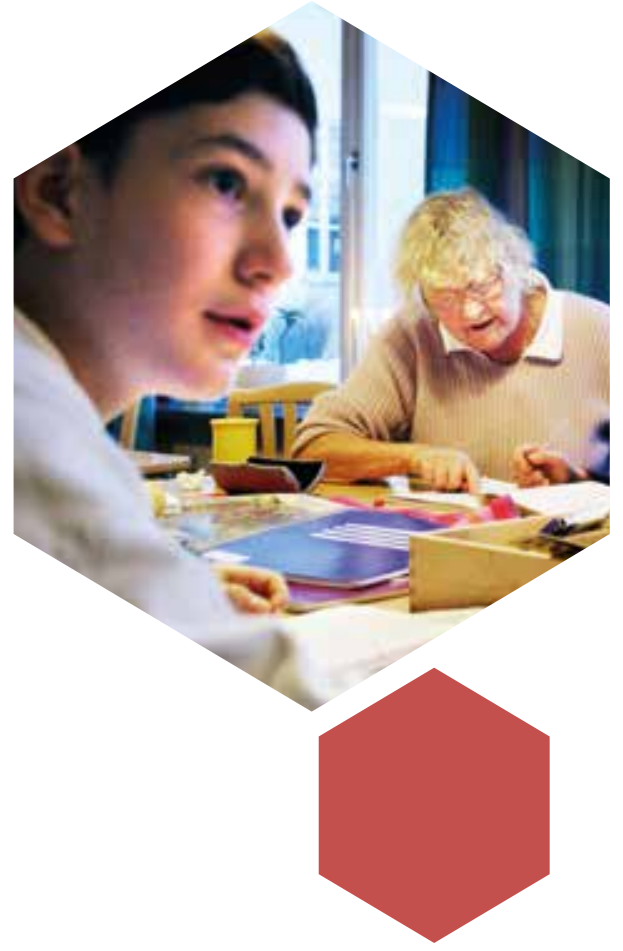




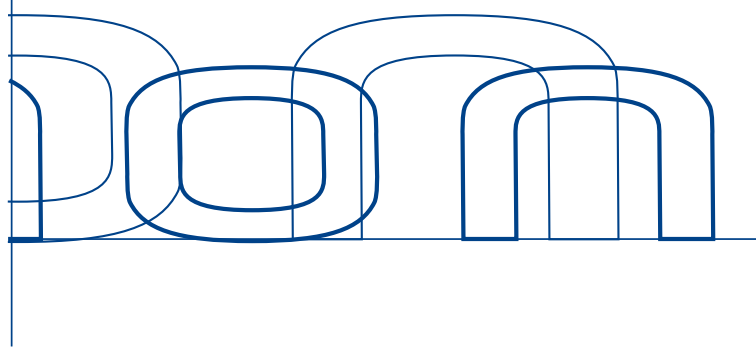

Norden i Skolen under Foreningerne Nordens Forbund. 61 skoler er tilmeldt, og konkurrencens website har haft 11.000 unikke brugere. Temaet for Klimaduellen i 2015 bliver madspild, bæredygtige indkøbsvaner og metoder til affaldshåndtering, inspireret af de nordiske grøn vækst-projekter.

Læringsportalen www.nordeniskolen.org er et undervisningstilbud til nordiske lærere, som arbejder med emnerne Sprog \& Kultur og Klima \& Natur. Portalen har 3.800 registrerede brugere fordelt på 2.000 skoler, som samlet har 40.000 elever. Visionen med temaerne under Klima \& Natur er at indarbejde natur- og samfundsfag i en nordisk kontekst, sikre en faglig forankring inden for klima, bæredygtighed og grønne løsninger og understøtte elevernes innovative kompetencer.

I 2015 bliver Klimaduellen oversat til engelsk, grønlandsk, færøsk og samisk og udvikles endvidere som app til mobiler og tablets. Derved bliver konceptet mere tilgængeligt for børn og unge i Arktis og internationalt.

\section{Biophilia}

Uddannelsesprogrammet Biophilia blev etableret som et nordisk samarbejdsprojekt under det islandske formandskab i 2014. Programmet udforsker samspillet mellem videnskab, kreativitet, teknologi og musik. Hensigten ar at understøtte børn og unges læring og innovative kompetencer gennem tværvidenskabelige og kreative læringsmetoder.

Nordiske forskere, videnskabsmænd, kunstnere og lærere har i samarbejde med den islandske kunstner Björk udviklet undervisningsidéer til projektet. Undervisningsmaterialet er tilgængeligt på www. biophiliaeducational.org, der også fungerer som forum for udveksling af idéer og erfaringer.

Programmet er endvidere en samarbejdsplatform for forskere i Norden, som skal fremme unges interesse i forskning og uddannelse gennem en nordisk turné med forelæsninger, kurser og interaktiv undervisning. Nordiske vidensformidlere blev præsenteret for projektet i 2014, og ydermere er der produceret vejledninger, film- og undervisningsmateriale til turnéen.
PILOT - Viden om bæredygtig udvikling - Nordisk efteruddannelse for voksne

Nordiske efteruddannelsesorganisationer har lanceret en pilotuddannelse i bæredygtig udvikling. Målet er at øge viden om bæredygtighed og udforske, hvordan den kan fremmes såvel lokalt som globalt.

19 elever fra hele Norden har deltaget i fire samlinger Norge, Danmark, Sverige og Finland. Deltagerne gennemfører hver sit projekt, som er knyttet til det lokalmiljø, de repræsenterer. Arbejdet foregår i tværnordiske grupper, hvor deltagerne udveksler erfaringer for at kunne anvende og videreformidle nordiske styrker $\mathrm{i}$ arbejdet for en bæredygtig og retfærdig verden.

Pilotens metode og pædagogiske idé er indtil videre præsenteret på syv internationale konferencer og seminarer og i flere tidsskrifter. Projektet evalueres i 2015 for at afklare, om uddannelsen kan udbydes i større skala og som et permanent efteruddannelsestilbud til voksenundervisere i Norden.

\section{Implementering av Rio+20 på de nordiske} universiteter og højere uddannelsesinstitutioner Projektet har gennemført en større undersøgelse af implementeringen af bæredygtige udviklingstiltag på nordiske universiteter og højere uddannelsesinstitutioner. Formålet har været at øge samarbejdet mellem institutionerne og engagere beslutningstagere i implementeringen af Rio+20-målsætningerne for bæredygtighed, som vedrører institutionernes drift og uddannelsesudbud. Resultaterne præsenteres i 2015 i en rapport, som giver et overblik over bæredygtighedsniveauet i nordiske uddannelsesinstitutioner og beskriver styringsmekanismer, drivere og barrierer, som har indflydelse på implementeringen.

\section{Nordic Master i grøn vækst}

Nordic Master i grøn vækst er en toårig masteruddannelse på 120 ECTS-point, som skal etableres i samarbejde mellem mindst tre universiteter i de nordiske lande samt Færøerne, Grønland og Åland. Undervisningen vil foregå på engelsk for at tiltrække nordiske, europæiske og internationale studerende. Nordic Master bliver introduceret i juni-september 2015, og konsortiet bag uddannelsen sammensættes i oktober. Studerende optages på uddannelsen i 2016 og 2017. 


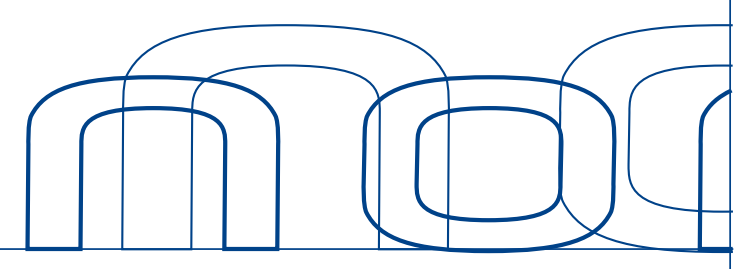

\section{Forbrugerfleksibilitet på det nordiske elmarked}

\section{Opdrag:}

- $\quad \emptyset g e$ fokus på efterspørgselssiden i elmarkedssamarbejdet i Norden, blandt andet ved at fremme fleksibelt elforbrug og en nordisk erfaringsudveksling og koordinering omkring udvikling og implementering af intelligente net og elmålere

- Fremme et samarbejde med førerende aktører inden for industrien og servicesektoren for at udveksle erfaringer og best practice om forbrugerfleksibilitet og energieffektivisering

\section{Ansvar:}

Energiministrene i samarbejde med erhvervsministrene

Rapporten Demand response in the Nordic electricity market udkom i 2014 og fremsætter to hovedkonklusioner. For det første konkluderer rapporten, at der er behov for yderligere forståelse for den fremtidige efterspørgsel på elmarkedet, før man effektivt kan igangsætte fleksibilitetsfremmende tiltag. For det andet bør der være en overordnet strategi for at sikre en optimal udnyttelse af fleksibilitet, uanset om denne kommer fra forbrug, produktion, lagring eller ved forstærkninger af nettet.

Før forbrugerfleksibilitet kan komme på tale som et effektivt instrument til at balancere udbud og efterspørgsel på elmarkedet, skal der udvikles ny teknologi. Rapporten anbefaler de nordiske lande at se nærmere på potentialet i at udvikle teknologier, der kan reagere på prissignaler for forbrugere.

Rapporten konkluderer også, at forbrugerfleksibilitet bedst sikres gennem effektive og transparente markeder. Der er to afgørende forudsætninger for øget fleksibilitet, nemlig at forbrugerne kan monitorere deres elforbrug i realtid, og at de har et klart prisincitament for at justere deres forbrug efter de aktuelle elpriser. Det er vigtigt at forstå, at forbrugerfleksibilitet ikke er et mål i sig selv, men et middel til bedre at balancere markedet.

Projektet er færdigstillet, men Nordisk Ministerråds Elmarkedsgruppe arbejder videre med forbrugerfleksibilitet på elmarkedet. Elmarkedsgruppen har anmodet NordREG, de nordiske energiregulatorer, om indspil til, hvordan rapportens konklusioner kan føres videre

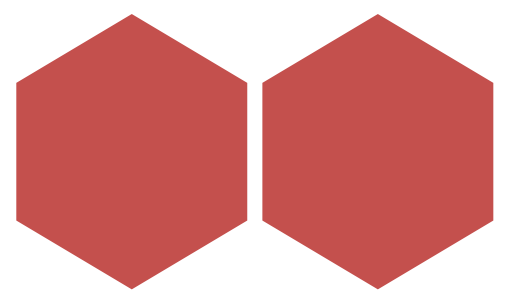




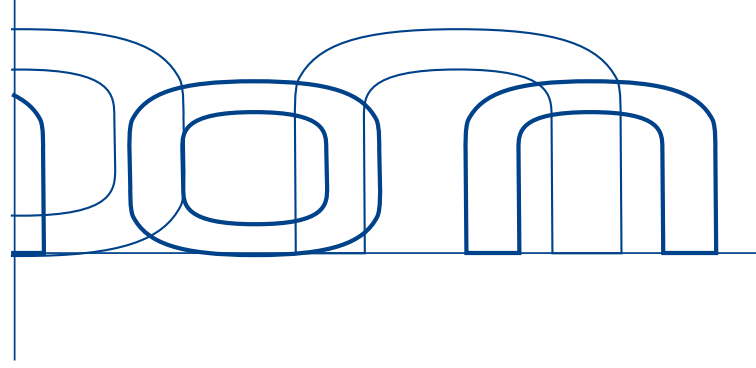

4

\section{Grønne tekniske normer og standarder}

\section{Opdrag:}

- Identificere 4-5 nøgleområder på bygge- og anlægsområdet, hvor tekniske normer og standarder egner sig til nordisk koordinering, samt udarbejde forslag til, hvordan barriererne på disse områder kan modvirkes

- Gennem det nordiske samarbejde gøre EU's arbejde med økodesign og energimærkningskrav på flere produkttyper mere ambitiøst

- $\quad$ Sikre, at arbejdet inden for de eksisterende arbejdsplaner gennemføres

- $\quad$ Arbejde for, at fremtidige arbejdsplaner om energirelaterede og energiforbrugende produkter omfatter produktkrav, som har interesse ud fra et nordisk perspektiv

\section{Ansvar:}

Energiministrene i samarbejde med erhvervs- og miljøministrene

Tre hovedprojekter blev iværksat som en del af indsatsområdet grønne tekniske normer og standarder. Projekterne fokuserer på byggestandarder, svanemærkning af bygningsrenovering samt markedstilsyn med økodesign og energimærkning.

Flere af projekterne har haft en målsætning om at påvirke internationale processer, og de nordiske forslag om fælles europæiske standarder er sat på dagsordenen hos CEN, den europæiske standardorganisation, i foråret 2015. På nordisk niveau arbejder man videre med udvikling af svanemærkning for renovering, som forventes færdigudviklet i 2016. Initiativet har desuden ført til væsentlige fremskridt i det nordiske samarbejde om markedstilsyn af økodesign og energimærkning.

\section{The Nordic region as a standard maker}

The Nordic region as a standard maker består af tre projekter, som skal påvirke regelværket for europæisk byggeri i fremtiden. Målsætningen har været at skabe nye europæiske standarder, som tager

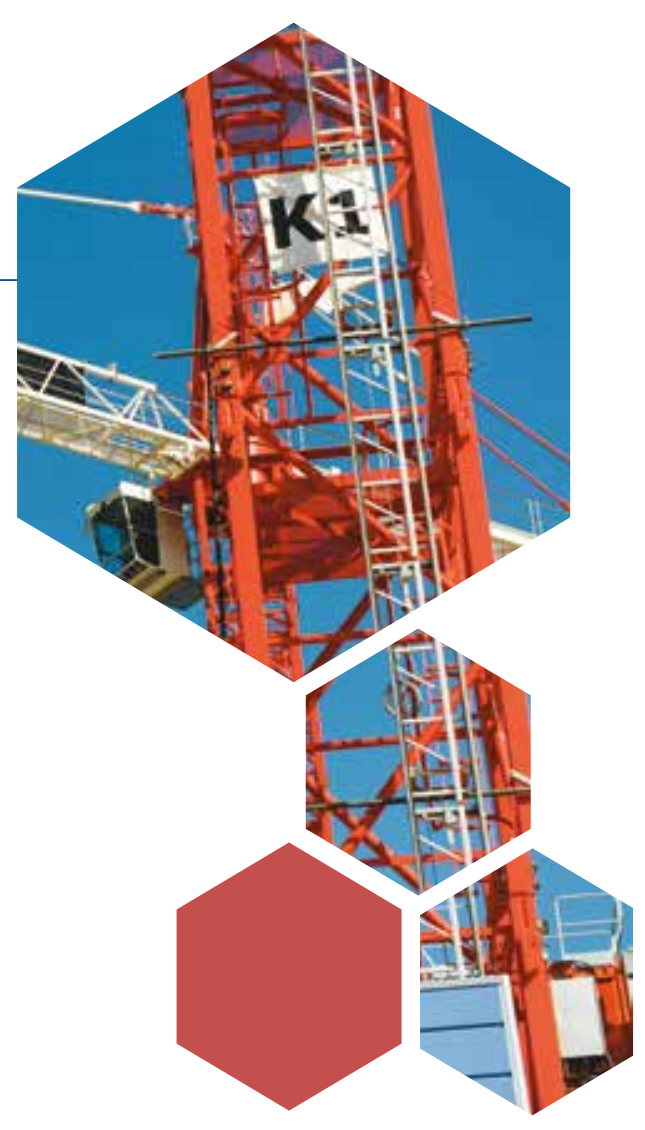

udgangspunkt i de nordiske traditioner og regler på tre områder: produkt- og bygningsdeklarationer, bygningsrenovering og indendørsklima.

Hensigten bag projektet Future EU regulation on product and building declarations er at påvirke implementeringen af EU's bygningsreglement og øge fokus på bæredygtighed og genbrug af byggematerialer. Ambitionen er at sikre, at EU's måde at anskue livscyklusanalyse på ligger i forlængelse af de fremgangsmåder, som allerede bruges i nordisk erhvervsliv. Projektet har udviklet produktlivscyklusanalyser for isoleringsmateriale og stålprodukter, som imødekommer de politiske krav til genanvendelse i EU og lever op til den europæiske standard. Præciseringen vil betyde, at nordiske virksomheder kommer på forkant med produktkravene og kan bevare deres produktions- og dokumenteringsmetoder.

Holdbar renovering af eksisterende bygninger resulterede i et nordisk oplæg til en ny europæisk standard for klassificering af bygninger med hensyn til renovering. Udgangspunktet for forslaget er nordisk ekspertise inden for bygningsrenovation og muligheden for eksport af nordiske arkitekt- og ingeniørydelser.

Indendørsklima og frivillige klassificeringsstandarder har lavet et tilsvarende oplæg til en europæisk standard for indendørsklima. Formålet er at sikre større vægt på indendørsklima i energirenovering af eksisterende bygninger med afsæt $\mathrm{i}$ de nordiske traditioner $\mathrm{i}$ forhold til luft, lys og lyd.

De nordiske forslag om fælles europæiske standarder er sat på dagsordenen hos CEN, den europæiske standardiseringsorganisation, i foråret 2015. Desuden 


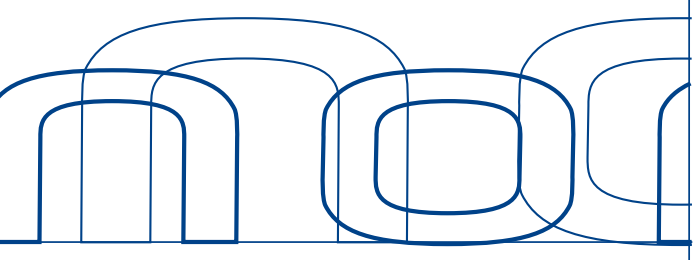

planlægges en målrettet public affairs-indsats over for relevante organisationer og EU-institutioner i juni 2015.

\section{Svanemærkning af bygningsrenovering}

Målet har været at udvikle kriterier for svanemærkning af bygningsrenovering. Kriterierne skal beskrives $i$ et kriteriedokument for svanemærkning af renovering og en tilhørende baggrundsrapport. Svanemærket vil kunne bruges af private og offentlige bygherrer, som udfører bæredygtig renovering.

Svanemærkets kriterier skal tilpasses alle de nordiske lande baseret på en samlet vurdering af bygningernes miljømæssige tilstand. Standarden skal stille strenge men opnåelige krav, således at byggeaktører kan bruge svanemærket som dokumentation for deres bidrag til bæredygtig udvikling af byggeriet.

Standarden skal videreføre svanemærkets styrkeområder i forhold til byggeri såsom begrænset brug af skadelige kemikalier, godt indeklima, lavt energibehov, mindre $\mathrm{CO}_{2}$-udslip og kontrol med byggeprocessen. Arbejdet tager også udgangspunkt i resultaterne fra Holdbar renovering af eksisterende bygninger og en markedsundersøgelse udarbejdet af konsulentvirksomheden Sweco.
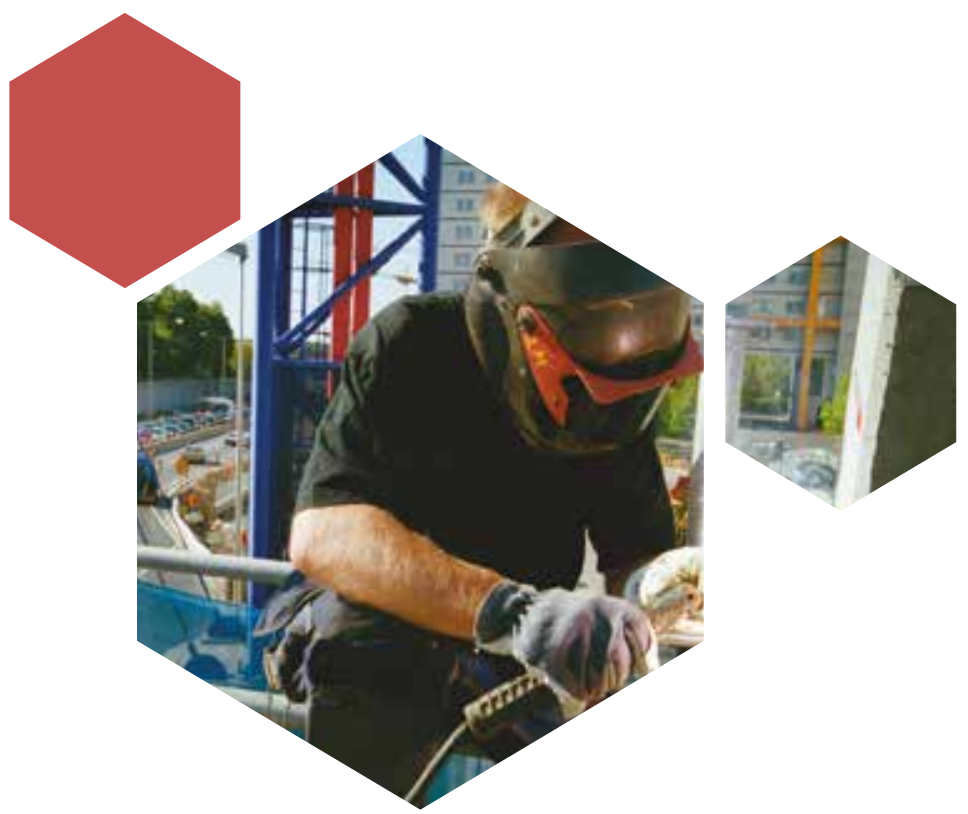

Et udkast til kravstandarden for svanemærkning af renovering vil blive udviklet i 2015 og derefter sendt til høring. Standarden færdigudvikles i 2016 på baggrund af testresultater og feedback fra nordiske entreprenører og ekspertgrupper, hvorefter den skal godkendes af Nordisk miljømærkenævn.

\section{Nordsyn}

Formålet med Nordsyn er at forbedre markedstilsynet med økodesign og energimærkning i Norden. Projektet henvender sig primært til de nordiske markedstilsynsmyndigheder, tilsvarende europæiske myndigheder og producenter af energirelaterede produkter.

Nordsyn har bidraget væsentligt til det nordiske samarbejde om markedstilsyn med økodesign og energimærkning i form af koordinering, øget dialog om fortolkning of lovgivning, samarbejde om test- og informationsaktiviteter og deling af testresultater og markedstilsynsplaner.

Nordsyn har iværksat en række dybdegående studier af emnet, heriblandt Effekter av marknadskontroll, Strategiska Nordiska Produkter og Survey SME, samt en række guidelines om markedstilsyn og teknisk dokumentation.

I 2015 fokuserer Nordsyn på tre initiativer, Kontinuerliga arbetsmetoder, Hur överbygga barriärer för samarbete og projektet Utmaningar för marknadskontroll (marknadskontroll av svåra produkter). Projektet afrundes i 2015 med en afslutningskonference og slutrapport, mens samarbejdet mellem de nordiske markedstilsynsmyndigheder fortsætter.

Nordsyns vigtigste resultater præsenteres på ECEEE Summer Study on Energy Efficiency i juni og ved efterårets ADCO-møde, som samler de europæiske markedstilsynsmyndigheder. 


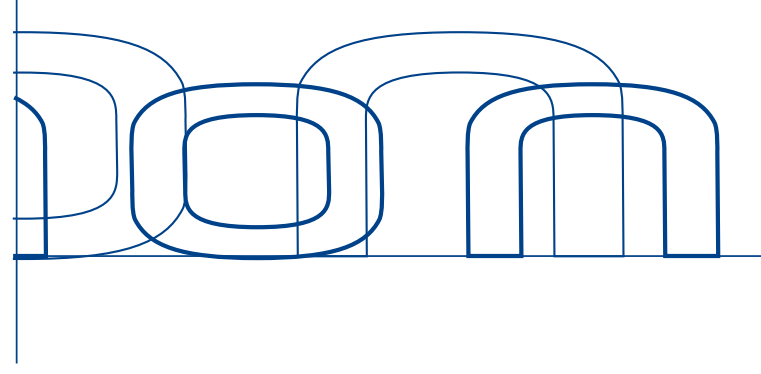

5

\section{Grønne offentlige indkøb i Norden}

\section{Opdrag:}

- Igangsætte et arbejde, som i første trin identificerer områder og produktgrupper, hvor grønne indkøbsstandarder er mest effektive sammenlignet med andre instrumenter

- Undersøge i næste trin mulighederne for at koordinere grønne indkøbsstandarder på nordisk niveau

- Inkludere grønne forretningsmodeller i arbejdet, hvor området udgør et nyttigt supplement til mærkningsordningerne

\section{Ansvar:}

Erhvervsministrene i samarbejde med miljø- og energiministrene

Arbejdet har handlet om at identificere de mest relevante produkter og services i forhold til grønne offentlige indkøb (Green Public Procurement - GPP) og vurdere muligheden for at udvikle fælles nordiske standarder på området. Analysen viser, at særlige nordiske kriterier ikke ville give markante fordele. I stedet fokuseres arbejdet nu på at udarbejde forslag til fælles nordiske indsatser for at styrke et samlet nordisk marked og udviklingen af miljøvenlige produkter og services.

Erhvervs- og miljøsektorerne gennemførte i 20122013 et forstudie om GPP og potentialet for et videre nordisk samarbejde herom. De anbefalinger, som blev fremsat efterfølgende, ansås dog ikke for at

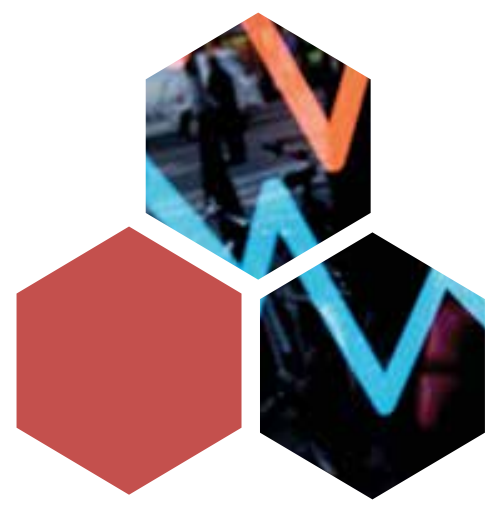

modsvare statsministrenes opgave i tilstrækkelig grad. Nordisk Ministerråd og Nordic Innovation fik til opgave at udvikle et projekt, som bedre imødekom statsministrenes ønsker.

Rapporten Status on GPP in the Nordic countries blev udarbejdet i 2015 for at identificere de mest relevante produkter og services i forhold til GPP og vurdere muligheden for at udvikle fælles standarder på området. Analysen viser, at produktkategorierne allerede identificeres af nationale og internationale myndigheder. EU's GPP-kriterier danner således grundlaget for de nordiske landes kriterier. I lyset af de nordiske aktørers allerede eksisterende samarbejde er konklusionen, at Norden ikke ville opnå markante fordele ved at etablere fælles kriterier.

Til gengæld fremhæves styrken i et fælles nordisk marked, som ville give større købekraft og mulighed for at stille mere specifikke krav til produkterne. Det samlede nordiske budget for offentlige indkøb er mere end 66 milliarder euro per år. Innovative offentlige indkøb til et samlet nordisk marked repræsenterer således et stort potentiale for at fremme udviklingen af miljøvenlige produkter og services.

Lederskab er ifølge rapporten afgørende for vellykket implementering af grønne kriterier for offentlige indkøb. Beslutningstagere opfordres til at bidrage politisk og økonomisk til udviklingen af effektive indkøbsstrukturer og veldefinerede GPP-målsætninger samt at sørge for kvalificeret uddannelse og kompetenceudvikling. Desuden pointeres behovet for bedre monitoreringssystemer for at vurdere den økonomiske og miljømæssige effekt af GPP. Nordic Innovation organiserer, blandt andet på baggrund af ovennævnte rapport, en workshop i første halvår af 2015. Workshoppen skal samle de involverede aktører i et fors $ø g$ på at identificere fælles nordiske indsatsområder og projekter, som kan danne grundlaget for det fortsatte arbejde. 


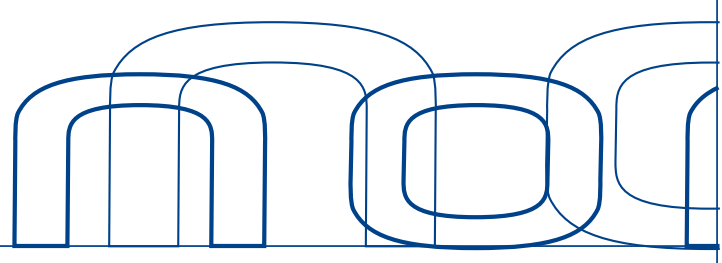

6

\section{Udvikling af teknologi og metoder til affaldshåndtering}

\section{Opdrag:}

- Udvikle fælles nordiske metoder og teknikker til at udvælge affaldsgrupper som eksempelvis bygge- og anlægsaffald, madspild og ophugningsaffald fra jern og metal, hvor der er potentiale for at skabe en ressourceeffektiv genanvendelse af affald

\section{Ansvar:}

Miljøministrene og fødevareministrene (FJLS) i samarbejde med energi- og erhvervsministrene

Flere projekter er blevet lanceret for at forbedre håndteringen af plast- og tekstilaffald samt reducere madspild i Norden. Projekterne har kortlagt nuværende mangler og bidraget med forslag til fremtidige løsningsmodeller samt retningslinjer og policyanbefalinger for det fortsatte nordiske samarbejde.

Resultaterne viser blandt andet, at øget genanvendelse af affald markant vil forbedre ressourceeffektiviteten i Norden, formindske udledningen af drivhusgasser og skabe nye jobs i regionen. Resultaterne forventes at bidrage væsentligt til det nordiske samarbejde i de kommende år og har også vakt stor internationale interesse.

\section{Ressourceeffektiv genanvendelse af plast- og tekstilaffald}

Nordisk Affaldsgruppe lancerede på vegne af miljøministrene initiativet Resource efficient recycling of plastic and textile waste for at følge op på statsministrenes ambition om effektiv og bæredygtig udnyttelse af affaldsressourcer. Initiativet består af tre projekter om genanvendelse af plastaffald, som fokuserer på plastemballage fra husholdningsaffald, plastaffald på genbrugscentraler og plast fra elektronisk affald. På tekstilområdet har yderligere tre projekter arbejdet mod øget indsamling, sortering, genbrug og genanvendelse af tekstiler i regionen.

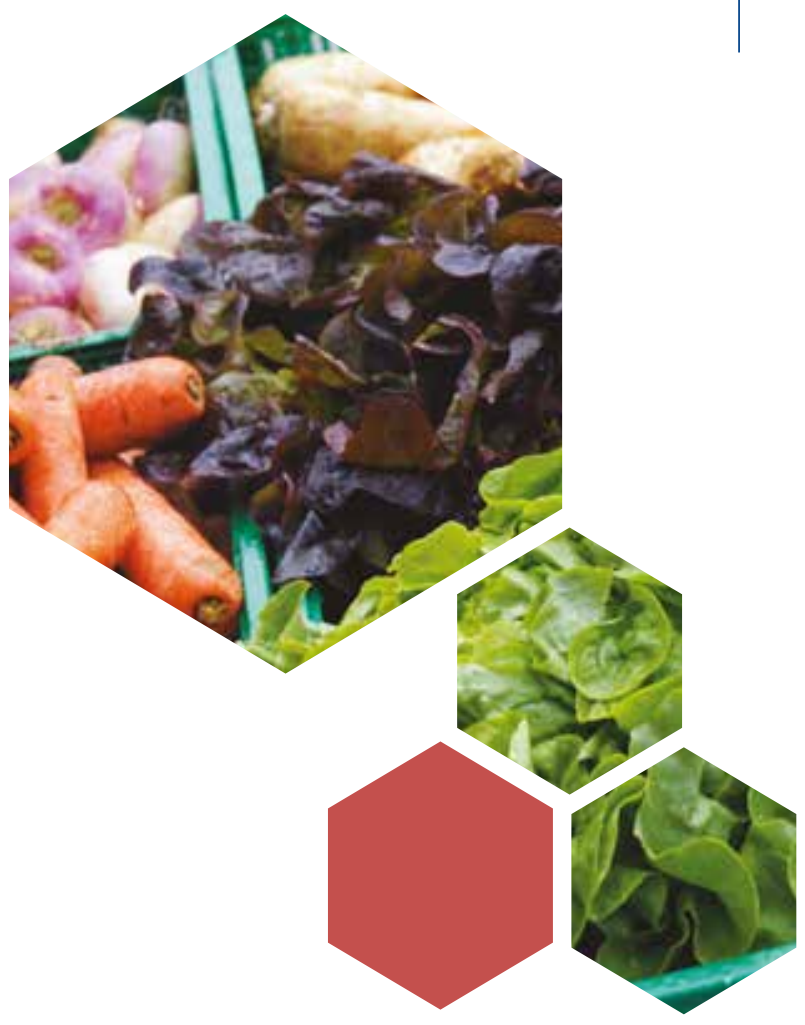

Projekternes resultater viser, at indsamling og genanvendelse af plast- og tekstilaffald i Norden kan øges betragteligt. Bare fra kommunale affaldsstrømme kan landene potentielt indsamle og genanvende yderligere 700.000 tons plast. En større mængde plast, som indleveres på genbrugscentre, samt plast fra elektronisk affald kunne ligeledes udnyttes i større grad end i dag. Øget genanvendelse af plastaffald ville forbedre ressourceeffektiviteten i Norden, reducere udledningen af drivhusgasser og skabe nye jobs i regionen.

Samlet har projekterne foreslået konkrete strategier og værktøj til, hvordan private og offentlige aktører i plastværdikæden kan bidrage til øget indsamling og genanvendelse af plast. To af projekterne har desuden udarbejdet policyanbefalinger til nordiske beslutningstagere med henblik på at øge materialegenanvendelsen af plastaffald.

På tekstilområdet viser resultaterne, at øget indsamling, sortering, genbrug og genanvendelse af tekstiler kan reducere miljøbelastningen fra tekstilforbruget $i$ Norden, styrke regionens konkurrenceevne og skabe grønne jobs. Det årlige forbrug af nye tekstiler i de nordiske lande er 350.000 tons, mens der kun indsamles 120.000 tons brugte tekstiler om året. Miljøpotentialet er stort, da produktionen af bare ét kilo tekstiler svarer til udledning af 15 kilo $\mathrm{CO}_{2}$. 


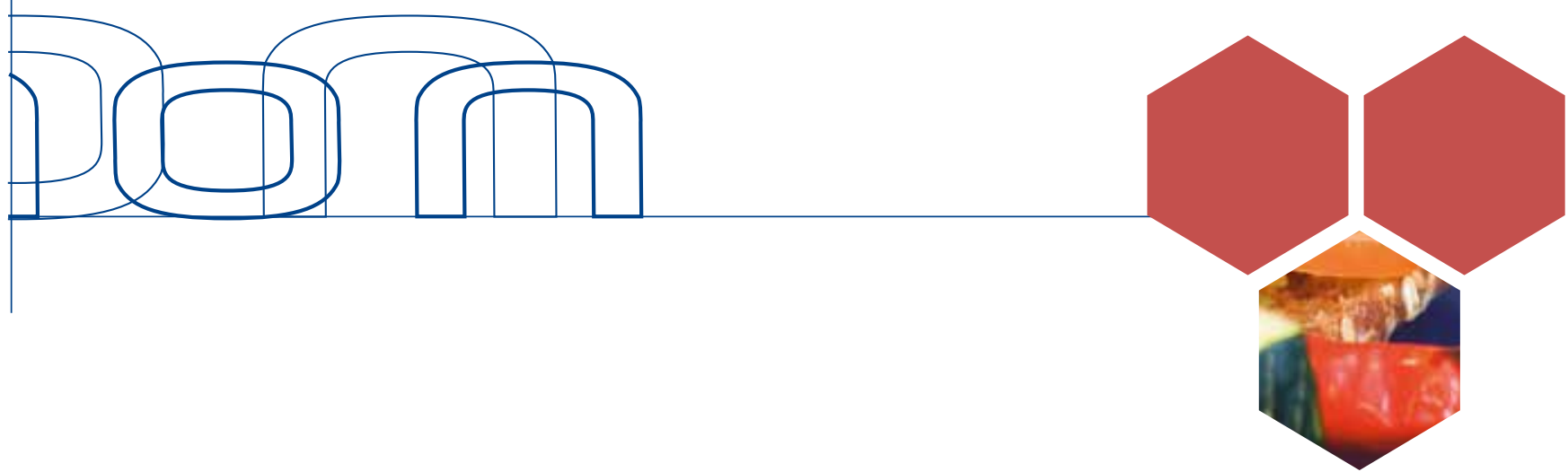

Nordiske eksperter har udgivet tre kernedokumenter, som danner grundlaget for en fordobling af indsamling, genbrug og genanvendelse af brugte tekstiler i Norden. Målsætningen er, at tekstilerne skal genbruges så ofte som muligt i løbet af deres funktionelle levetid og bagefter genanvendes. Denne form for omlægning kan potentielt føre til over 4000 nye arbejdspladser i regionen.

Arbejdet med både plast- og tekstilaffald fortsætter i 2015 og 2016. Det danske formandskab af MR-M i 2015 har lanceret en handlingsplan mod en bæredygtig tekstil- og modebranche, som vil bygge videre på resultaterne fra grøn vækst-projekterne om tekstilaffald.

Resultaterne fra plast- og tekstilprojekterne vil desuden blive præsenteret i europæiske og internationale fora med henblik på at inspirere til mere miljøvenligt forbrug, produktion og håndtering af plast og tekstiler.

\section{Madspild}

Fødevareministrene iværksatte i 2012 tre projekter for at mindske madspild i de nordiske lande. Projekterne har undersøgt, hvordan madspild i primærproduktionen kan reduceres, og hvordan datomærkninger og omfordeling af fødevarer til værdigt trængende kan bidrage til at begrænse madspildet i Norden.

Ligesom i resten af verden er der et stort potentiale for at reducere madspild i de nordiske lande. Målet med projekterne har været at skabe viden om madspild i primærproduktionen, og hvordan det kan undgås, bidrage til at producenter datomærker fødevarer på en måde, som minimerer madspild, og fremme sikker og effektiv distribution af overskudsfødevarer til værdigt trængende.

Resultaterne viser, at lovgivning om datomærkning af fødevarer fortolkes forskelligt i Norden, blandt andet i vurderingen af holdbarhedstid og brug af 'Sidste anvendelsesdato'. Det videre arbejde skal munde ud i fælles nordiske holdninger til anvendelsen af datomærkning for at undgå madspild. Resultaterne indikerer også, at en mere effektiv omfordeling af fødevarer kan bidrage til at reducere madspildet $\mathrm{i}$ Norden. Omfordelingen foregår hovedsageligt direkte fra giver til modtager, hvilket indikerer, at madbanker kunne spille en større rolle.

En undersøgelse af madspild i primærsektorerne er undervejs. 6000 spørgeskemaer er sendt ud til producenter inden for landbrug og fiskeopdræt for at skabe et overblik over omfang og årsager til madspild i produktionen. En rapport om emnet udgives i begyndelsen af 2016.

Ved at fortsætte det nordiske samarbejde om madspild forventes det, at regionen kan indtage en førende rolle og fremføre en stærk fælles vision i EU omkring udviklingen af en grøn økonomi. Projekternes resultater indgår allerede i det europæiske samarbejde, hvor projektgruppen har præsenteret nordiske erfaringer, modeller og værktøj til at undgå madspildmed vægt på primærproduktion, datomærkning og omfordeling af mad. Resultaterne har mødt stor interesse fra EU's Expert Group on Food Losses and Food Waste.
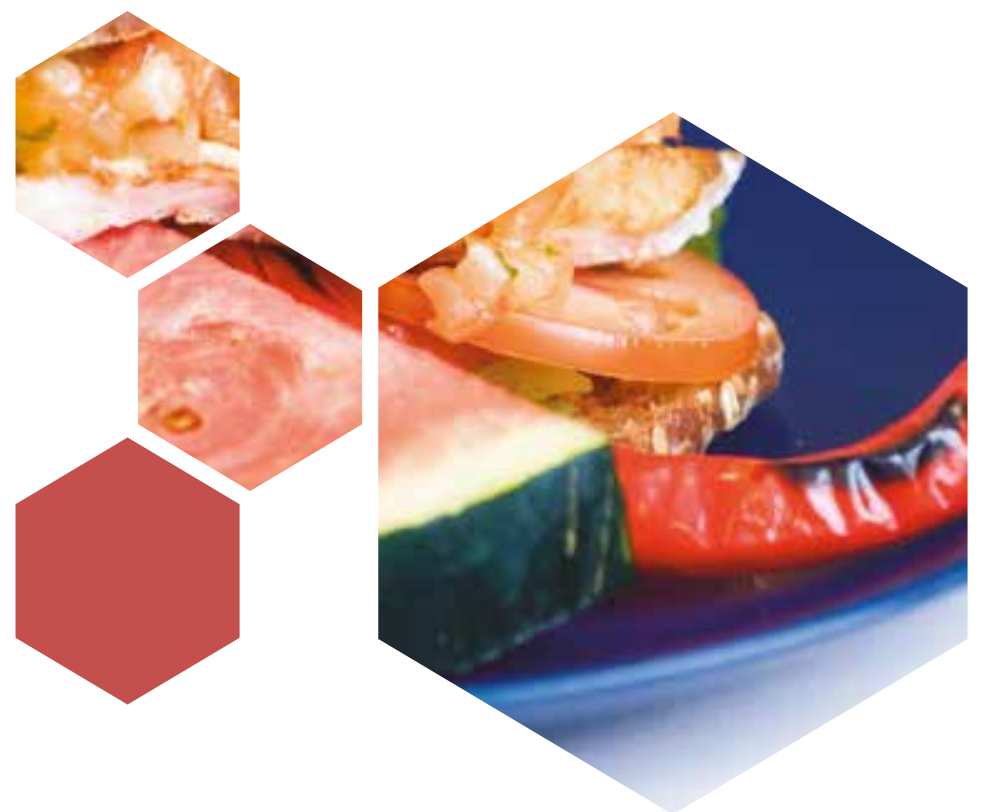


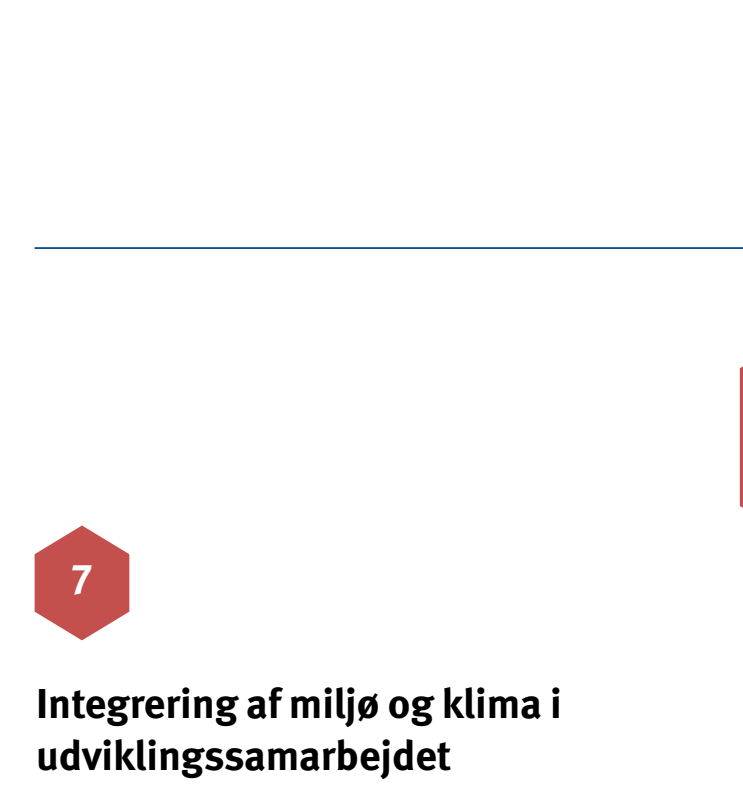

\section{Opdrag:}

- $\quad$ Fremme samspillet i det nordiske udviklingssamarbejde og styrke dets grønne fokus

\section{Ansvar:}

Bistands- og udviklingsministrene, miljøministrene

Projektet viser, hvordan lavindkomstlande kan udfase ineffektiv og miljøskadelig statsstøtte til fossile brændsler. Forskningsresultater indikerer, at en reformering af disse subsidier kan reducere den globale $\mathrm{CO}_{2}$-udledning markant med mellem 6 og $13 \%$ inden 2050. Projektet har leveret en række konkrete og operationelle resultater, som hver især spiller en vigtig rolle i arbejdet med udfasning af statsstøttede fossile brændsler, og som allerede er anvendt i forbindelse med nationale subsidiereformer og internationale klimaforhandlinger.

Projektet har blandt andet udviklet en beregningsmodel, som gør det muligt at kalkulere, hvor meget udviklingslandene kan reducere deres emissioner ved at udfase statsstøtten til fossile brændsler. Det opstiller desuden scenarier for, hvordan besparelserne fra subsidiereformen i stedet kan investeres i bedre energieffektivitet og vedvarende energi. På den måde støtter det nordiske initiativ udviklingslandenes omstilling til en grøn økonomi.

I 2014 udgav projektet en rapport, som beskriver mulighederne for et tættere nordisk samarbejde om omlægningen af subsidier til fossile brændsler. Rapporten ser på de sociale omkostninger, der er forbundet med at beholde subsidierne, og analyserer mulighederne for at udvikle sociale velfærdssystemer ved at udfase støtten. Desuden er der udgivet en "How to - guidebook", som operationaliserer ovenstående data og viden samt hjælper landene til at indregne det individuelle lands budgetterede reduktioner af

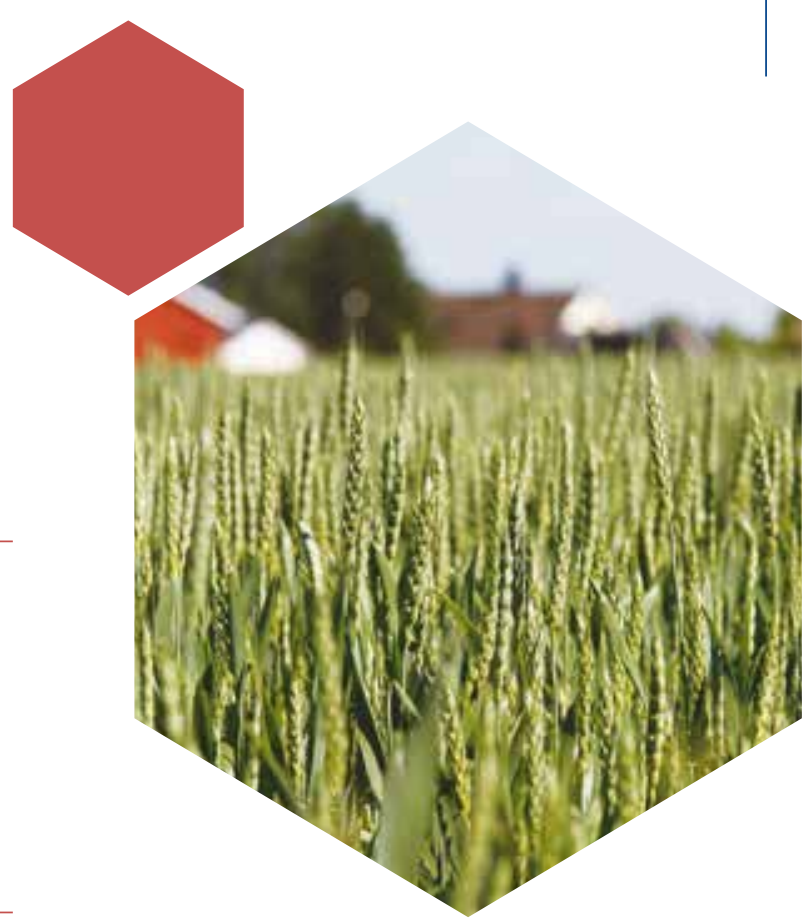

$\mathrm{CO}_{2}$-udledninger ved at reformere statstøtte til fossile brændsler.

Dataene og informationerne er især værdifulde for de lande, der ønsker at reducere deres udslip som led i klimaforhandlingerne. To udviklingslande gør allerede brug af projektets beregningsmodel i forbindelse med afrapportering til UNFCCC om landenes reduktionspotentialer.

Resultaterne fra initiativet er allerede blevet formidlet og anvendt i forbindelse med en række internationale klimaforhandlinger, blandt andet COP20 i Lima og UNFCCC's klimakonferencer i 2014 og 2015. Helt konkret er rapporten allerede hentet fra norden.org over 1200 gange, siden den blev publiceret i februar 2015 .

I løbet af 2015 vil projektet blive præsenteret i alle de væsentligste internationale fora, som beskæftiger sig med subsidier til fossile brændstoffer, inklusive UNFCCC og ved forhandlingerne om FN's Post 2015udviklingsagenda. Projektets slutrapport udkommer i juni 2015.

Projektet er et samarbejde mellem Danmark, Finland, Norge og Sverige, Nordic Environment Finance Cooperation (NEFCO), International Institute for Sustainable Development og to partnerlande. Det blev lanceret $\mathrm{i}$ forlængelse af den nordiske involvering i Friends of Fossil Fuel Subsidy Reform-gruppen. 


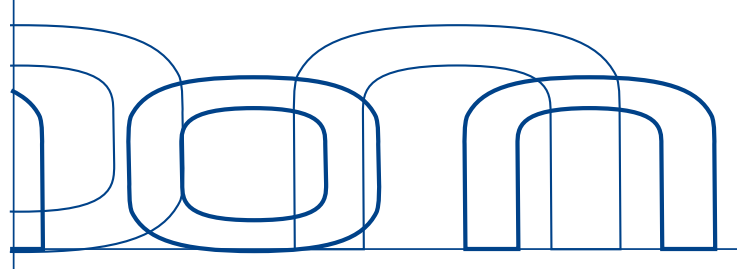

8

\section{Finansiering af grønne investeringer og virksomheder}

\section{Opdrag:}

- $\quad$ Komme med forslag til, hvordan de nordiske finans-, erhvervs- og energiministre kan koordinere og intensivere deres indsatser i finansielle institutioner, hvor de nordiske lande som centrale aktører kan støtte og stimulere finansieringen af grønne forretninger og investeringer

Ansvar:

Finansministrene i samarbejde med erhvervs- og energiministrene

Tre rapporter er produceret i forbindelse med initiativet. Resultaterne viser, at de potentielle effekter af en styrket nordisk indsats inden for de finansielle institutioner er marginale sammenlignet med generelle økonomisk-politiske instrumenter, som kan påvirke hele samfundsøkonomien. NIB og NEFCO besidder trods et tydligt miljøfokus en relativt lille markedsandel.

Finansministrene iværksatte i 2012 en indledende unders $\emptyset$ gelse for at belyse, hvordan de nordiske lande kunne koordinere og styrke deres indsats i de nordiske finansinstitutioner for at fremme finansiering af grønne virksomheder og investering i grøn vækst.

Konklusionen er, at de institutioner, hvor de nordiske lande har et betydeligt ejerskab - dvs. den Nordiske Investeringsbank, NIB og det nordiske miljøfinansieringsselskab, NEFCO - allerede gør en stor indsats for at finansiere grønne investeringer og miljøsatsninger. Analysen viser dog også, at deres beskedne markedsandel begrænser deres indflydelse i forhold til det samlede investeringsbehov.

Finanssamarbejdet besluttede i 2013 at udvide analysen i samarbejde med miljøsektoren til også at omfatte landenes brug af markedsbaserede instrumenter, som kan fremme grønne investeringer. Analysen sammenligner landenes idéer til, hvordan de bedre kan udbedre såkaldte markedsfejl ved anvendelsen af økonomisk-politiske instrumenter - eksempelvis ved at kompensere for lave priser på $\mathrm{CO}_{2}$-udslip.

Indsatsen blev afsluttet i 2015 med en opsummerende rapport, som beskriver de nordiske landes vigtigste prioriteringer for at fremme grønne investeringer og bedre miljø. De samlede resultater viser, at der er yderligere potentiale for grønne investeringer i Norden, især på investeringstunge områder som energi og transport og materiale- og affaldshåndtering. Endvidere bliver det slået fast, at landene fortsat bør være bevidste om, hvorvidt deres økonomisk-politiske prioriteringer skaber det rigtige incitament for grønne investeringer. 


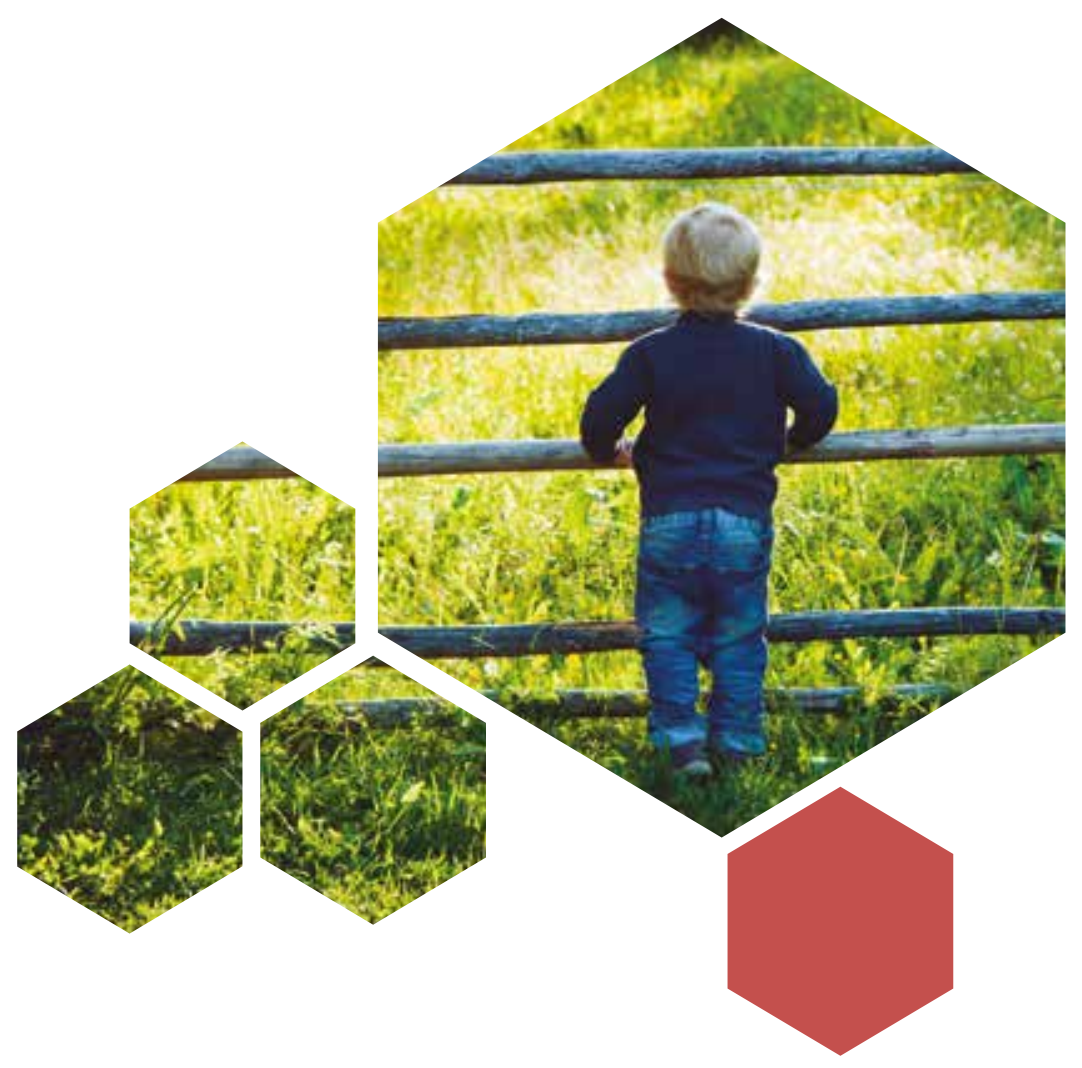




\section{norden}

Nordisk Ministerråd

Ved Stranden 18

DK-1061 København K

www.norden.org

\section{Norden - førende inden for grøn vækst}

Status til de nordiske statsministres sommermøde 2015.

De nordiske statsministre bad i november 2011 Nordisk Ministerråd lancere et tværsektorielt grøn vækst-initiativ ud fra otte anbefalinger på udvalgte områder. Opgaven var baseret på rapporten Norden - ledande i grön tillväxt, udarbejdet af en nordisk arbejdsgruppe.

Udgangspunktet for initiativet var, at de nordiske lande i fællesskab langt bedre kan udnytte deres position i forhold til øget energieffektivisering, udvikling af bæredygtig energi samt innovations- og forskningssatsninger og høje målsætninger på miljø- og klimaområdet.

Fagministrene konkretiserede arbejdsgruppens otte anbefalinger til projektaktiviteter, der løber til 2016. Denne statusrapport præsenterer projekternes vigtigste resultater.

Mere information om initiativet er tilgængelig på ministerrådets hjemmeside www.norden.org/greengrowth 